\title{
Guest Editorial: Special Issue on Supporting Mathematics Teacher Educators' Knowledge and Practices for Teaching Content to Prospective (Grades K-8) Teachers
}

\author{
Aina Appova \\ The Ohio State University, USA \\ Rachael M. Welder \\ Texas A\&M University, USA \\ Ziv Feldman \\ Boston University, USA
}

\section{Background}

Recent research and political initiatives in the U.S. have suggested that teacher education programs are providing inadequate preparation for prospective elementary teachers (PTs), many of whom are not developing the deep, conceptual knowledge of the mathematics needed to become effective teachers (e.g., Conference Board of the Mathematical Sciences (CBMS), 2001, 2012; Greenberg \& Walsh, 2008). These issues stem from, among other things, a lack of clarity and consensus within the field about what PTs should learn and experience while in mathematics content-focused courses (e.g., Ball, Sleep, Boerst, \& Bass, 2009; Zaslavsky, 2007) and a lack of preparation and support for the mathematics teacher educators (MTEs) who teach such courses (e.g., Bergsten \& Grevholm, 2008).

In the U.S., mathematics content-focused teacher education courses for prospective elementary teachers (henceforth, throughout the entire special issue, referred to as content courses) are primarily undergraduate courses that mainly focus on developing the mathematical knowledge of particular age-level content that PTs are preparing to teach. This special issue focuses on content courses specifically designed for elementary PTs who are studying to obtain 
certification to teach school children between the ages of 5-12 (U.S. equivalent of Grades K-8). For the purpose of this special issue, we define mathematics teacher educators (MTEs) as the professionals who teach these content courses or who work with elementary PTs "to develop and improve the teaching of mathematics" (Jaworski, 2008, p. 1).

There has been increased interest and effort among MTEs to study and share the work they are doing in their mathematics content courses to strengthen PTs' development of mathematical knowledge for teaching (e.g., Ball et al., 2009, Hill \& Ball, 2004; Hill, Ball, \& Schilling, 2008) and pedagogical content knowledge (or content-specific pedagogy) (e.g., An, Kulm, \& Wu, 2004; Lampert et al., 2013; Shulman, 1987). However, aspects of this body of research are still fairly limited and highlight a lack of clarity and consensus about the particular content PTs should learn and the pedagogy PTs should understand and experience while in mathematics content courses (e.g., Bergsten \& Grevholm, 2008; Zaslavsky, 2007). This issue is further complicated by the fact that content courses for PTs are predominantly taught by MTEs who have limited experiences working with elementary school students or curriculum and often do not receive the training and support necessary to effectively attend to the needs of elementary PTs (Masingila, Olanoff, \& Kwaka, 2012). This special issue seeks to address a number of these concerns by providing research-based practical recommendations to support the work of MTEs who teach (or are preparing to teach) mathematics content to elementary PTs. Below we describe the nature of this special issue and its research- and practice-based contributions to the field.

\section{Contribution to the Field}

The overarching goal of this project was to help MTEs who teach content courses to elementary (K-8) PTs translate theory and research into directly applicable classroom practices that can support PTs in developing the content and professional knowledge needed to effectively 
teach (K-8) mathematics. To this end, we solicited articles that are (a) grounded in policy and research, and (b) substantiated by explicit recommendations, suggestions, and implications for supporting MTEs' classroom-based practice, knowledge, and pedagogy.

The result of these efforts is a collection of 16 "theory-driven, practice-focused," peerreviewed articles, ranging from literature reviews and policy analyses to classroom-based capsules, self-studies, and reflections on practice. The articles in this special issue have been collectively written by 46 MTEs, across the U.S., contributing to the current mathematics teacher education literature in three major areas:

a) the unique nature of content courses specifically designed for elementary PTs (e.g., Bass, 2005; Berk \& Hiebert, 2009; Cady, Hopkins, \& Hodges, 2008; Hiebert, Morris, \& Glass, 2003; Hiebert \& Morris, 2009; Marin, 2014; Monroe, 2013; Nolan, 2015; Tzur, 2001; Zazkis \& Chernoff, 2008);

b) the professional development of MTEs who teach content courses for elementary PTs (e.g., Chick \& Beswick 2013; Dixon, Andreasen \& Stephan, 2009; Rowland, Turner \& Thwaites, 2014; Superfine \& Li, 2014; Zopf, 2010); and,

c) the expertise and teaching practices of MTEs who teach content courses for elementary PTs (e.g., Castro, 2006; Chval, Lannin, \& Bowzer, 2008; Goodell, 2006; Steele, 2008; Thanheiser et al., 2016; Van Zoest \& Stockero, 2008; Zazkis, Liljedahl, \& Chernoff, 2008).

Below we will briefly describe each article and highlight its specific contribution to one of these major research areas, which we will refer to as themes.

\section{Theme 1: The Unique Nature of the Curriculum, Knowledge, and Participants in Mathematics Content Courses for Prospective Elementary Teachers}

In the U.S., the majority ( $80 \%)$ of K-8 teacher preparation programs include at least two 
semester-long mathematics content courses (typically comprised of 3-5 hours per week of instructional time for approximately 14 weeks) completed by PTs in the first few years of their undergraduate studies (Masingila et al., 2012). Although most of these courses are taught in mathematics departments (Masingila et al., 2012), they are specifically designed for elementary PTs and offered separately from other college-level mathematics courses that PTs may take (Greenberg \& Walsh, 2008; Lutzer, Rodi, Kirkman, \& Maxwell, 2007). Not only is the student population of these courses unique, but the curricula used in these courses also differs substantially from a typical college-level mathematics course. These courses cover a variety of topics from the K-8 school mathematics curriculum, but at a much deeper level than that of which K-8 students are expected to learn. Thus, the articles included in this particular theme help to shed light on the unique nature of these courses and how they differ from other undergraduate mathematics courses in terms of their goals, design, and student population, including the distinctive knowledge and expertise needed by the MTEs who teach these courses.

We begin this theme with a scholarly piece by Castro Superfine, Prasad, Welder, Olanoff, and Eubanks-Turner who help to conceptualize the mathematical knowledge needed for teaching teachers (MKTT) and offer insights into the ways they, as MTEs, use this knowledge to teach mathematics to K-8 PTs. The authors illustrate various aspects of their own use of MKTT to support K-8 PTs in relearning, or reconstructing, their previously learned knowledge of K-8 mathematics. The next article, written by Zhang, Brown, Joseph, and He discusses the dilemmas faced by MTEs in making difficult decisions about which content to emphasize during content courses and why. Drawing on policy documents and curriculum standards, as well as textbook analyses and relevant research, the authors provide specific recommendations on how MTEs might select topics for inclusion in their content courses. Following this work, Felton-Koestler 
offers additional recommendations urging MTEs to focus on preparing teachers to make connections between mathematics and real-world contexts that involve exploring, analyzing, and proposing solutions for current social and political issues. Felton-Koestler identifies the knowledge bases that teachers (and MTEs) must draw upon to effectively discuss and teach sociopolitical issues in mathematics courses. Lastly, the articles in this theme examine the prevalence of mathematics anxiety among K-8 PTs through the summary of research findings provided by Karunakaran. Her work highlights known causes of PTs' mathematics anxiety and research-based recommendations that MTEs can use in their content courses to help reduce PTs' mathematics anxiety.

Collectively, this set of articles offers insight into why content courses are especially critical for the mathematical and professional development of PTs as future K-8 educators and how specific knowledge bases and expertise may be necessary for MTEs to be better equipped for teaching these courses. This raises further questions about the availability of professional learning opportunities for MTEs to develop the necessary knowledge and teaching expertise relevant to their work with K-8 PTs, especially in content courses. These questions bring us to our next theme focusing on the need for professional development opportunities for MTEs.

\section{Theme 2: Professional Development for Mathematics Teacher Educators Focused on the Teaching of Mathematics Content Courses for Prospective Elementary Teachers}

Nearly all (90\%) mathematics content courses for PTs are taught and developed in departments of mathematics (Masingila et al., 2012; Greenberg \& Walsh, 2008). Yet, “few people trained as mathematicians have thought deeply about how courses for prospective or practicing elementary school teachers might be taught, and there is little support, professional development, or on-the-job training available for them" (CBMS, 2012, p. 35). Furthermore, even those with formal training in mathematics education often lack the PreK-12 teaching experience 
needed to ground their work with teachers in their experiences with PreK-12 students (Reys, Reys, Shih, \& Safi, 2019). Current estimates suggest $20 \%$ of all MTEs in higher education do not have any PreK-12 teaching experience (Reys et al., 2019) and the majority of instructors of content courses for elementary PTs do not have experiences working with or teaching mathematics to children (Bass, 2005; Hodgson, 2001; Masingila et al., 2012; Sztajn, Ball, \& McMahon, 2006). Given these issues, it is not surprising that Masingila et al. (2012) found that more than half of the MTEs in the field who teach content courses for elementary PTs feel unprepared and report lack of training, resources, and support at their institutions.

One way to address this issue is through the examination of mathematics education graduate studies, where researchers have found significant differences in the experiences and preparation of graduates from various doctoral programs (Reys et al., 2019). Of course, while addressing quality and consistency across doctoral programs is vital, it is requisite to keep in mind that, "it is unreasonable to expect that a Ph.D. program will fully prepare mathematics educators for the wide range of challenges and expectations they will confront" (Reys \& Reys, 2012, p. 290). Therefore, in addition to their doctoral preparation, MTEs will need opportunities to grow and adapt throughout their careers, which creates an urgent need for continued and multifaceted professional development.

Models of successful professional development for MTEs do exist, such as the STaR program for novice MTEs (Reys \& Reys, 2012), communities of practice, lesson study, peercollaborations, workshops, and MTE partnerships (e.g., Kimani, Olanoff, \& Masingila, 2012); however, research on this topic is still in its infancy. The need for further research is critical, especially given that teaching content to elementary PTs is often a regular (and sometimes primary) job responsibility of MTEs, regardless of their past training or expertise. 
Thus, in this special issue we included articles that provide models and recommendations for professional learning opportunities specifically focused on supporting MTEs in their work with elementary PTs. In the first article, Suppa, DiNapoli, Thanheiser, Tobias, and Yeo describe current institutional efforts for supporting novice MTEs who are teaching content for elementary PTs for the first time. The authors present implementation models for three different successful professional development platforms (they have experienced), including: working with a mentor, using specific educative curriculum materials as professional development guides, and participating in a collaborative teaching environment. In the next article, Jackson, Hauk, Tsay, and Ramirez offer an additional approach by developing an online short-course to help improve the classroom instruction of MTEs, particularly for those who are new to teaching elementary PTs. Their article also shares a conceptual model that can be utilized when designing professional development opportunities for university faculty who are non-educators or new to the role and responsibilities of MTEs.

Furthermore, not all institutions have the capacity to provide professional development support for MTEs. Outside support might be particularly useful for smaller colleges and universities where a single MTE might be employed to teach all mathematics teacher-preparation courses. One possibility to consider is building a peer-collaboration or community of practice with MTEs at other institutions. In this theme, we included an article by Applegate, Dick, Soto, and Gupta, in which the authors share their own experiences, as a group of geographicallydispersed novice MTEs, in collaborating to implement lesson study. Their article provides a nice model for using technology to support long-distance peer-collaborations, within the context of lesson study, and highlights the ways in which this model supported their development of MKTT. 
We recognize that the professional development of MTEs is critically needed, primarily focusing around the issues of classroom practice, including (a) the development of effective lessons and teaching strategies that promote PTs' learning of the content they will teach and (b) the fostering of experiences and positive dispositions that PTs can take into their future classrooms. Thus, our goal for the last theme in this special issue was to offer the field scholarly articles that serve a multilayered purpose in contributing to the mathematics education literature and supporting the professional development of MTEs. The articles included in this theme discuss a wide-range of activities, mathematics tasks, lesson ideas, and enactments of specific teaching strategies that MTEs can directly utilize in their own classrooms, regardless of the curriculum materials they are using. Also, similar to the other two themes, these articles include a dedicated "practitioner" component to help inform, reform, and impact MTEs' practice and professional knowledge for teaching content courses.

\section{Theme 3: Activities, Lesson Ideas, Examples, and Suggestions for Mathematics Content Courses to Help Promote Prospective Elementary Teachers' Learning}

Bass (2005) argued that strengthening the mathematical preparation of teachers requires extensive research examining the classroom practices of those who teach mathematics to teachers, and that those who teach these courses and "have not turned serious attention to mathematics education often fail to appreciate the cognitive and epistemological subtleties of elementary mathematics instruction" (p. 419). Similarly, Masingila et al. (2012) suggested that mathematics instructors who teach content courses for K-8 PTs should not only know the mathematics content required for teaching teachers, but also how to support PTs' in developing the content knowledge necessary to effectively teach K-8 students, namely mathematical knowledge for teaching (MKT). We support these suggestions and argue that improving (mathematics) teacher preparation requires developing a database of classroom-based artifacts 
and resources for MTEs. Doing so allows MTEs to contribute and collaborate through those resources as part of their own continued professional development.

The articles included in this theme address a wide range of classroom- and practitionerbased issues that MTEs grapple with regularly, including the selection and design of tasks, to help develop the various domains of PTs' mathematical knowledge for teaching, and the development of effective strategies, to facilitate PTs' engagement with mathematical learning practices. Two articles in this theme focus specifically on identifying characteristics of mathematical tasks that support PTs' learning. First, Litster, MacDonald, and Shumway describe tasks that allow for multiple entry points and solution strategies and leverage the power of analyzing examples and counterexamples in tasks to promote problem solving and reasoning. Next, Feldman, Wickstrom, Ghosh Hajra, and Gupta provide detailed examples of three tasks and their implementation in content courses, illustrating how "uncertainty" can be effectively used in developing PTs' specialized content knowledge, a domain of MKT. Both articles provide explicit recommendations for how MTEs can develop and select mathematical tasks to achieve these goals in their content courses.

Furthermore, the next four articles provide practical guidance for developing and assessing various aspects of PTs' MKT. Through conducting a literature review, Appova and Taylor share research-based lesson ideas for strengthening PTs' pedagogical content knowledge. In contrast, Johnson and Olanoff discuss their own classroom use of transformative learning theory to illustrate how MTEs can help PTs reflect on and deepen their "incoming" content knowledge by creating disorienting dilemmas that require PTs to reconsider and re-connect to new understandings and re-learn mathematics. Furthermore, Kuennen and Beam share specific examples of classroom activities and discuss how various aspects of them, including the 
integration of manipulatives, K-8 curricula, and examples of children's mathematical thinking, can support PTs' development of MKT. This set of articles is further supported by the work of Patterson, Parrott, and Belnap, in which the authors offer specific strategies that MTEs can use to assess PTs' MKT, including focusing on mathematical representations and specific aspects of children's thinking.

The next four articles in this theme discuss specific classroom practices that can help MTEs facilitate PTs' engagement in the practices that support the learning of mathematics. For example, Max and Welder provide a synthesis of the evolution of K-12 school mathematics standards in the U.S. to help novice MTEs become more familiar with the professional organizations and documents that led to the development of these learning practices. Specifically, they focus on a standard that addresses a learner's ability to analyze and critique the (mathematical) reasoning of others and offer examples of tasks and resources that can help MTEs nurture PTs in developing these learning practices while in content courses. Similarly, Hallman-Thrasher, Rhodes, and Schultz emphasize and describe five practices that MTEs can utilize to help PTs construct more robust mathematical explanations. In contrast, Bernander, Szydlik, and Seaman take a broader approach by offering a compendium of practical and research-based recommendations for engaging PTs in learning habits encompassing the eight Standards of Mathematical Practice of the Common Core State Standards (National Governors Association Center for Best Practices, Council of Chief State School Officers, 2010).

Our experiences (and anecdotes from other MTEs) suggest that MTEs, especially those new to the field, often reach out to peers for help in teaching content courses for PTs due to a lack of professional development and classroom-based resources. Moreover, this theme resulted in the largest compilation of articles in the entire special issue, confirming the urgent need for 
building and sharing practitioner knowledge within the MTE community, particularly for teaching content courses. We are pleased to offer these articles to our colleagues and hope that they will provide an added support for this difficult work.

\section{Development of this Special Issue: Collaboration, Solicitation, and Review Process}

The guest editors' work in the field of improving the preparation on elementary PTs through studying and supporting the work of MTEs started long before we met and it was the similarity of our work that brought us together and launched our initial conversations about developing this special issue (e.g., Appova, 2018; Appova \& Taylor, 2019; Feldman, Thanheiser, Welder, Tobias, Hillen, \& Olanoff, 2016; Max \& Welder, 2019; Olanoff, Welder, Prasad, \& Castro Superfine, 2018; Taylor \& Appova, 2015; Thanheiser, Olanoff, Hillen, Feldman, Tobias, \& Welder, 2016; Tobias, Olanoff, Hillen, Welder, Feldman, \& Thanheiser, 2014; Welder, Appova, Olanoff, Taylor, \& Kulow, 2016; Welder \& Champion, 2011; Welder \& Jong, 2012; Welder \& Simonsen, 2011; Yow, Eli, Beisiegel, McCloskey, \& Welder, 2016).

Our work together officially began by us organizing a research symposium at the 2016 Annual Conference for the Association of Mathematics Teacher Educators, titled "Supporting Mathematics Teacher Educators' Work with Prospective Elementary Teachers: A Look Through Multiple Perspectives" (Taylor, Appova, Welder, \& Feldman, 2016). This symposium helped to recruit experts from the field to provide feedback on our research and consider our idea of moving the professional conversation to the next level by creating an open platform for MTEs to share and discuss their work via scholarship. The symposium generated a strong interest from the field, and many researchers expressed interests in contributing to this platform.

Later in 2016, we organized a working group at the Annual Conference for the North American Chapter of the International Group for the Psychology of Mathematics Education 
(PME-NA; Welder, Appova, Olanoff, Taylor, \& Kulow, 2016). This working group, titled "Improving preservice elementary teacher education through the preparation and support of elementary mathematics teacher educators," brought together more than 50 MTEs and instructors of content courses (with over a dozen attending virtually) to discuss their current work and research interests around this topic. During the three working-group sessions, authors began forming groups around shared interests, identifying writing teams and working on collaborative abstracts to potential articles for this special issue.

Following PME-NA, the guest editors began to formally solicit topics and inquiries for the special issue from the session participants, as well as other colleagues in the field, including colleagues in Canada. These invitations were followed by the official "intent to submit" notices from the authors. We asked interested authors to submit 200-word abstracts summarizing their intended manuscript topics. After reviewing the abstracts (submitted in summer 2017), the guest editors selected and invited twenty (20) author teams to submit manuscripts (by March 2018) for potential publication in this special issue. The abstracts were selected based on their relevance to the special issue and a set of specific criteria (see the Manuscript and Review Criteria section below). Once all (20) corresponding manuscripts were received, we randomly assigned a number (1-20) to each manuscript and used this numbering system to preserve the "doubleblind" practice of peer-reviews. Each manuscript was also assigned to one of the guest editors, who served as the handling editor.

\section{Manuscript and Review Criteria}

This special issue was aimed explicitly at addressing a population of MTEs who teach content courses to PTs. This population involves a variety of individuals, including (but not limited to) mathematics education faculty, mathematicians, adjunct instructors, current and 
former K-12 classroom teachers, graduate students, and professionals who prepare novice MTEs (Greenberg \& Walsh, 2008). Thus, in soliciting and reviewing abstracts and articles for this special issue, we required that authors write their pieces to be accessible to a broad audience of readers.

Furthermore, due to the lack of practice-based and classroom-oriented research in the field, especially for MTEs' work related to teaching content to elementary PTs, we required all manuscripts to be both research-grounded and practitioner-oriented. Specifically, regardless of the nature of the article (e.g., theory-building, self-reflections, single-study reports, philosophical papers) all authors were required to dedicate a sizable portion of their manuscripts to making explicit practice-based recommendations regarding, but not limited to, MTEs' knowledge, backgrounds, expertise, work, practices, and/or professional development as they relate to teaching content to K-8 PTs. Furthermore, authors providing recommendations based solely on their own practices, as MTEs, were also required to make research-based connections and ground their ideas within relevant literature.

These criteria were explicitly built into a manuscript review rubric (see Appendix A) that the guest editors developed to help reviewers assess each manuscript according to these requirements (using a 4-point Likert scale). During each round of reviews, reviewers were also asked to provide detailed notes and feedback for both the authors and editors. Lastly the reviewers were asked for their final recommendation for each manuscript by selecting: accept/accept with minor revisions, accept with major revisions, revise and resubmit, or reject.

The major differences between the manuscripts that received "accept with major revisions" and "revise and resubmit" were: relevance to the special issue, quality of writing, soundness of research, and adherence to the identified criteria. For example, if a manuscript was 
relevant to the issue and sound in research design and procedures but required substantial rewriting of the sections to ensure better quality and/or adherence to the rubric, the "revise and resubmit" decision was assigned. Furthermore, the authors were explicitly informed that a resubmission of the "revise and resubmit" manuscript did not guarantee acceptance for publication and that the manuscript would require additional reviews to reach a final decision.

All manuscripts underwent four (4) rounds of reviews: two (initial) rounds of doubleblind reviews by external and internal reviewers and two (subsequent) rounds of reviews by the editorial team. For every manuscript, at each round of review, the editors compiled the feedback and sent it via email (often with suggested "tracked changes" within the submitted document) to the corresponding authors. Below, we describe each round of review and provide an (itemized) overview and timeline of our review process.

\section{External and Internal (Multi-Round) Peer-Reviewed Process}

During the time in which the invited authors were writing their manuscripts (August 2017-March 2018), we contacted numerous experts in the field and recruited a total of forty (40) colleagues (not contributing to the project) who agreed to review the manuscripts. These reviews were conducted in a double-blind peer-review practice. Each manuscript (submitted in March 2018) was assigned a minimum of two external reviewers. After receiving the feedback from external reviewers (June 2019), all three guest editors read each of the 20 submitted manuscripts in full (first-pass editorial review), provided their own review using the rubric, and then read the feedback received from external reviewers. We discussed each manuscript at length to resolve any disagreements in regards to suggested manuscript decisions. All external reviewer and editorial feedback and decisions were compiled and sent to the authors in September 2018. All authors, except those who received "reject" decisions, were asked to 
submit their revised manuscripts by December 2018 .

After receiving 17 revised manuscripts (December 2018), we began the second round of reviews comprised of randomly assigning the manuscripts in a "merry-go-around" fashion to other contributing teams of authors. In other words, all author teams who were currently working on a manuscript for potential publication were asked to review another group's manuscript. The second round of review was also conducted in a double-blind peer-review practice, again using the rubric we created.

After receiving feedback from the internal review teams (April 2018), the handling editor and at least one other guest editor read and reviewed each of the revised manuscripts (any manuscripts of concern were reviewed by all three guest editors). Decisions were made collectively after careful considerations and discussions among the editors addressing both the editors' and the internal reviewers' feedback. The authors were provided feedback from the internal reviewers and combined feedback from the three editors, in the form of a "tracked changes" document ranging from quick suggestions to extensive feedback and requests for further rewrites and/or revisions. Decisions from this second round of review were sent out by June 2019, asking authors to submit revisions by September 2019. One additional manuscript was rejected at this time.

After receiving the remaining 16 revised manuscripts (September 2019), we began the final round of internal editorial reviews, during which each handling editor carefully read and reviewed their set of manuscripts. The manuscripts that had garnered extra attention in the previous round were again reviewed by all three guest editors. After a careful review and consideration (and much deliberation), the editors reached an agreement that the remaining 16 manuscripts would be accepted for publication. Lastly, a fourth round of (editorial) review and 
feedback was conducted, which mainly involved the editors offering the authors specific feedback on editing, formatting, and polishing (proof-reading) their manuscripts. Final decisions were sent out in November 2019, and finalized "unblinded" manuscripts were received in December 2019. We have summarized this entire peer-reviewed process and timeline in Table 1. Table 1

Itemized Overview and Timeline for Peer-Review Process

\begin{tabular}{|c|c|c|c|}
\hline \multicolumn{4}{|c|}{ ROUND 1: EXTERNAL DOUBLE-BLIND PEER-REVIEW PROCESS } \\
\hline $\begin{array}{c}\text { Manuscripts } \\
\text { received }\end{array}$ & $\begin{array}{l}\text { Assigned reviewers per } \\
\text { manuscript }\end{array}$ & Decisions & Decisions sent \\
\hline March 2018 & $\begin{array}{l}2 \text { external reviewers }+3 \\
\text { editors }(5 \text { total })\end{array}$ & $\begin{array}{l}\text { Accept with Minor Revisions: } 2 \\
\text { Accept with Major Revisions: } 4 \\
\text { Revise and Resubmit: } 11 \\
\text { Reject: } 3\end{array}$ & September 2018 \\
\hline \multicolumn{4}{|c|}{ ROUND 2: INTERNAL DOUBLE-BLIND PEER-REVIEW PROCESS } \\
\hline $\begin{array}{l}\text { Manuscripts } \\
\text { received }\end{array}$ & $\begin{array}{c}\text { Assigned reviewers per } \\
\text { manuscript }\end{array}$ & Decisions & Decisions sent \\
\hline Dec 2018 & $\begin{array}{l}1 \text { internal reviewer }+3 \\
\text { editors ( } 4 \text { total), except } \\
\text { for the } 2 \text { "accept with } \\
\text { minor revisions" } \\
\text { manuscripts which were } \\
\text { assigned } 1 \text { internal } \\
\text { reviewer }+1 \text { editor ( } 2 \\
\text { total) }\end{array}$ & $\begin{array}{l}\text { Accept with Minor Revisions: } 9 \\
\text { Accept with Major Revisions: } 4 \\
\text { Revise and Resubmit: } 3 \\
\text { Reject: } 1\end{array}$ & June 2019 \\
\hline \multicolumn{4}{|c|}{ ROUND 3: INTERNAL EDITORIAL PEER-REVIEW PROCESS } \\
\hline $\begin{array}{l}\text { Manuscripts } \\
\text { received }\end{array}$ & $\begin{array}{l}\text { Assigned reviewers per } \\
\text { manuscript }\end{array}$ & Decisions & Decisions sent \\
\hline $\begin{array}{l}\text { September } \\
2019\end{array}$ & $\begin{array}{l}1 \text { editor for the } 9 \text { "accept } \\
\text { with minor revisions" } \\
\text { manuscripts, } 2 \text { editors for } \\
\text { the } 4 \text { "accept with major } \\
\text { revisions" manuscripts, } \\
\text { and } 3 \text { editors for the } 3 \\
\text { "revise and resubmit" } \\
\text { manuscripts }\end{array}$ & $\begin{array}{l}\text { Accept: } 16 \\
\text { Accept with Major Revisions: } 0 \\
\text { Revise and Resubmit: } 0 \\
\text { Reject: } 0\end{array}$ & November 2019 \\
\hline
\end{tabular}




\section{Conclusion}

Our overall goal for this special issue was to create an open-access resource for all MTEs including those who are new to the endeavor of teaching content to elementary PTs and those who are engaged in this work as graduate students, mathematicians, K-12 teachers, or experienced MTEs whose expertise lies elsewhere. The goal of offering this special issue was particularly important to us because, as MTEs, we too have struggled with teaching content courses for PTs and making effective transitions within our practice, and we have experienced firsthand how challenging this work can be. As a result, we sought to contribute to the field this special issue as a resource and as a professional development platform that all MTEs can use at all levels and points throughout their careers. More importantly, we hope this special issue serves as an impetus for the continued professional development of MTEs, by laying the foundation for building and expanding the (much needed) scholarship and stewardship in this area.

In concluding this project, we want to express our gratitude to the 46 authors who contributed to this special issue, for their arduous work and excellent scholarship. We extend our special thanks to Jim Hiebert and Dawn Berk for lending their expertise and supporting our work by writing the foreword to this special issue. We also acknowledge the work of 40 MTEs who served as external reviewers and provided helpful feedback to our authors (see Appendix B for a complete list). Finally, we want to thank Bharath Sriraman and the Mathematics Enthusiast for the opportunity to publish this special issue and make it available as an open-access resource.

\section{References}

An, S., Kulm, G., \& Wu, Z. (2004). The pedagogical content knowledge of middle school, mathematics teachers in China and the U.S. Journal of Mathematics Teacher Education, $7(2), 145-172$. 
Appova, A. (2018). Developing prospective teachers' mathematics orientations in the content courses. In E. Bergqvist and M. Österholm (Eds.), Proceedings of the 42nd Conference of the International Group for the Psychology of Mathematics Education, Vol. 2, (pp. 5966). Umea, Sweden.

Appova, A. \& Taylor, C. (2019). Expert mathematics teacher educators' purposes and practices for providing prospective teachers opportunities to develop pedagogical content knowledge in content courses. Journal of Mathematics Teacher Education. 22(2), 179204.

Ball, D. L., Sleep, L., Boerst, T. A., \& Bass, H. (2009). Combining the development of practice and the practice of development in teacher education. The Elementary School Journal, 109(5), 458-474.

Bass, H. (2005). Mathematics, mathematicians, and mathematics education. Bulletin of the American Mathematical Society, 42(4), 417-430.

Bergsten, C. \& Grevholm, B. (2008). Knowledgeable teacher educators and linking practices. In B. Jaworski \& T. Wood (Eds.), The international handbook of mathematics teacher education (Vol. 4, pp. 223-246). Rotterdam, The Netherlands: Sense Publishers.

Berk, D. \& Hiebert, J. (2009). Improving the mathematics preparation of elementary teachers, one lesson at a time. Teachers and Teaching: Theory and Practice, 15(3), 337-356.

Cady, J. A., Hopkins, T., \& Hodges, T. E. (2008). Lesson study as professional development for mathematics teacher educators. In F. Arbaugh \& P. M. Taylor (Eds.), Inquiry into Mathematics Teacher Education (Vol. 5, pp. 119-129). San Diego: Association for Mathematics Teacher Educators. 
Castro, A. M. (2006). Preparing elementary preservice teachers to use mathematics curriculum materials. The Mathematics Educator, 16(2), 14-24.

Chick, H. \& Beswick, K. (2013). Educating Boris: An examination of pedagogical content knowledge for mathematics teacher educators. In V. Steinle, L. Ball \& C. Bardini (Eds.), Proceedings of the 36th Annual Conference of the Mathematics Education Research Group of Australasia (MERGA 36, pp. 170-177). Melbourne, VIC: MERGA.

Chval, K. B., Lannin, J., \& Bowzer, A. (2008). The task design framework: Considering multiple perspectives in an effective learning environment for elementary preservice teachers. In F. Arbaugh \& P. M. Taylor (Eds.), AMTE Monograph 5: Inquiry into mathematics teacher education (pp. 35-45). San Diego, CA: Association of Mathematics Teacher Educators.

Conference Board of the Mathematical Sciences. (2001). The mathematical education of teachers (Issues in Mathematics Education, Vol. 11). Providence, RI: American Mathematical Society.

Conference Board of the Mathematical Sciences. (2012). The mathematical education of teachers II (Issues in Mathematics Education, Vol. 17). Providence, RI: American Mathematical Society.

Dixon, J. K., Andreasen, J. B., \& Stephan, M. (2009). Establishing social and sociomathematical norms in an undergraduate mathematics content course for prospective teachers: The role of the instructor. In D. S. Mewborn \& H. S. Lee (Eds.), AMTE Monograph 6: Scholarly practices and inquiry in the preparation of mathematics teachers (pp. 43-66). San Diego, CA: Association of Mathematics Teacher Educators. 
Feldman, Z., Thanheiser, E., Welder, R. M., Tobias, J. M., Hillen, A. F., \& Olanoff, D. (2016). When is a mathematical task a good task? In L. C. Hart, S. Oesterle, S. S. Auslander, \& A. Kajander (Eds.), The mathematics education of elementary teachers: Issues and strategies for content courses (pp. 9-24). Charlotte, NC: Information Age Publishing.

Goodell, J. (2006). Using critical incident reflections: A self-study as a mathematics teacher educator. Journal of Mathematics Teacher Education, 9(3), 221-248.

Greenberg, J. \& Walsh, K. (2008). No common denominator: The preparation of elementary teachers in mathematics by America's education schools. Washington, DC: National Council on Teacher Quality.

Hiebert, J. \& Morris, A. K. (2009). Building a knowledge base for teacher education: An experience in K-8 mathematics teacher preparation. The Elementary School Journal, $109(5), 475-490$.

Hiebert, J., Morris, A. K., \& Glass, B. (2003). Learning to learn to teach: An "experiment" model for teaching and teacher preparation in mathematics. Journal of Mathematics Teacher Education, 6(3), 201-222.

Hill, H. C. \& Ball, D. L. (2004). Learning mathematics for teaching: Results from California's mathematics professional development institutes. Journal for Research in Mathematics Education, 330-351.

Hill, H., Ball, D. L., \& Schilling, S. G. (2008). Unpacking pedagogical content knowledge: Conceptualizing and measuring teachers' topic-specific knowledge of students. Journal for Research in Mathematics Education, 39(4), 372-400. 
Hodgson, B. (2001). The mathematical education of school teachers: Role and responsibilities of university mathematicians. In D. Holton (Ed.), The teaching and learning of mathematics at university level (pp. 501-518). Dordrecht, The Netherlands: Kluwer.

Jaworski, B. (2008). Mathematics teacher educator learning and development: An introduction. In B. Jaworski \& T. Wood (Eds.), The international handbook of mathematics teacher education (Vol. 4, pp. 1-13). Rotterdam, The Netherlands: Sense Publishers.

Kimani, P. M., Olanoff, D. E., \& Masingila, J. O. (2012). Learning on the job: The preparation of mathematics teacher educators. Paper presented at the 16th Annual Conference of the Association of Mathematics Teacher Educators. Fort Worth, TX.

Lampert, M., Franke, M. L., Kazemi, E., Ghousseini, H., Turrou, A. C., Beasley, H., ... \& Crowe, K. (2013). Keeping it complex using rehearsals to support novice teacher learning of ambitious teaching. Journal of Teacher Education, 64(3), 226-243.

Lutzer, D. J., Rodi, S. B., Kirkman, E. E., \& Maxwell, J. W. (2007). Statistical abstract of undergraduate programs in the mathematical sciences in the United States. Washington, DC: American Mathematical Society.

Marin, K. A. (2014). Becoming a teacher educator: A self-study of the use of inquiry in a mathematics methods course. Studying Teacher Education, 10(1), 20-35.

Masingila, J. O., Olanoff, D. E., \& Kwaka, D. K. (2012). Who teaches mathematics content courses for prospective elementary teachers in the United States? Results of a national survey. Journal of Mathematics Teacher Education, 15(5), 347-358.

Max, B. \& Welder, R. M. (2019). Engaging prospective elementary teachers in standards for mathematical practice within content courses for teachers. In S. Otten, A. G. Candela, Z. de Araujo, C. Haines, \& C. Munter (Eds.), Proceedings of the 41st Annual Conference of 
the North American Chapter of the International Group for the Psychology of Mathematics Education (pp. 1141-1145). St. Louis, MO: University of Missouri. Retrieve (Open Access) from: https://s3.amazonaws.com/v3app_crowdc/assets/2/27/2768340edebc9e2c/PMENA19_020_Max.original.1571926683. pdf?1571926684

Monroe, E. E. (2013). Being and becoming a mathematics teacher educator in and for differing contexts: Some lessons learned. Studying Teacher Education, 9(2), 96-107.

National Governors Association Center for Best Practices, Council of Chief State School Officers. (2010). Common core state standards for mathematics. Washington D.C.: Authors.

Nolan, K. (2015). Beyond tokenism in the field? On the learning of a mathematics teacher educator and faculty supervisor. Cogent Education, 2(1), 1065580.

Olanoff, D., Welder, R. M., Prasad, P., \& Castro Superfine, A. (2018). Fractalization as a metaphor for mathematical knowledge for teaching teachers: Synthesizing the frameworks and exploring the consequences. In T. E. Hodges, G. J. Roy, \& A. M. Tyminski (Eds.), Proceedings of the 40th Annual Conference of the North American Chapter of the International Group for the Psychology of Mathematics Education (pp. 500-503). Greenville, SC: University of South Carolina \& Clemson University. Retrieve (Open Access) from: https://s3.us-east2.amazonaws.com/pmena2018/documents/public/PMENA+2018+Proceedings.pdf Reys, R. \& Reys, B. (2012). Supporting the next generation of "stewards" in mathematics education. Notices of the American Mathematical Society, 59(2), 288-290. 
Reys, R., Reys, B., Shih, J., \& Safi, F. (2019). Doctoral Programs in Mathematics Education: A status report of size, origin of program leadership, and recommended institutions. Notices of the American Mathematical Society, 66(2).

Rowland, T., Turner, F., \& Thwaites, A. (2014). Research into teacher knowledge: A stimulus for development in mathematics teacher education practice. $Z D M, 46(2), 317-328$.

Shulman, L. S. (1987). Knowledge and teaching: Foundations of the new reform. Harvard Educational Review, 57, 1-21.

Steele, M. D. (2008). Building bridges: Cases as catalysts for the integration of mathematical and pedagogical knowledge. In M. S. Smith \& S. N. Friel (Eds.), AMTE Monograph 4: Cases in mathematics teacher education: Tools for developing knowledge needed for teaching (pp. 57-72). San Diego, CA: Association of Mathematics Teacher Educators.

Superfine, A. C. \& Li, W. (2014). Exploring the mathematical knowledge needed for teaching teachers. Journal of Teacher Education, 65(4), 303-314.

Sztajn, P., Ball, D. L., \& McMahon, T. A. (2006). Designing learning opportunities for mathematics teacher developers. In K. Lynch-Davis \& R. L. Rider (Eds.), The work of mathematics teacher educators: Continuing the conversation, AMTE Monograph 3 (pp. 149-162).

Taylor, C. \& Appova, A. (2015). Mathematics teacher educators' purposes for K-8 content courses. In K. Beswick, T. Muir, and J. Fielding-Wells (Eds.), Proceedings of 39th Psychology of Mathematics Education Conference, Vol. 4, (pp. 241-248). Hobart, Tasmania, Australia.

Taylor, C., Appova, A., Welder, R., \& Feldman, Z. (January, 2016). Supporting mathematics teacher educators' work with prospective elementary teachers: A look through multiple 
perspectives. A Research symposium given at the Annual Conference of the Association of Mathematics Teacher Educators. Irvine, CA.

Thanheiser, E., Olanoff, D., Hillen, A., Feldman, Z., Tobias, J. M., \& Welder, R. M. (2016). Reflective analysis as a tool for task redesign: The case of prospective elementary teachers solving and posing fraction comparison problems. Journal of Mathematics Teacher Education, 19(2), 123-148.

Tobias, J. M., Olanoff, D., Hillen, A., Welder, R. M., Feldman, Z., \& Thanheiser, E. (2014). Research-based modifications of elementary school tasks for use in teacher preparation. In K. King (Ed.), Annual Perspectives in Mathematics Education: Using Research to Improve Instruction (pp. 181-192). Reston, VA: National Council of Teachers of Mathematics.

Tzur, R. (2001). Becoming a mathematics teacher-educator: Conceptualizing the terrain through self-reflective analysis. Journal of Mathematics Teacher Education, 4(4), 259-283.

Van Zoest, L. R. \& Stockero, S. L. (2008). Concentric task sequences: A model for advancing instruction based on student thinking. In F. Arbaugh \& P. M. Taylor (Eds.), AMTE Monograph 5: Inquiry into mathematics teacher education (pp. 47-58). San Diego, CA: Association of Mathematics Teacher Educators.

Welder, R. M., Appova, A., Olanoff, D., Taylor, C. E., \& Kulow, T. (2016). Improving preservice elementary teacher education through the preparation and support of elementary mathematics teacher educators. In M. B. Wood, E. E. Turner, M. Civil, \& J. A. Eli (Eds.), Proceedings of the 38th Annual Conference of the North American Chapter of the International Group for the Psychology of Mathematics Education (pp. 1713- 
1722). Tucson, AZ: University of Arizona. Retrieve (Open Access) from: http://www.pmena.org/pmenaproceedings/PMENA 382016 Proceedings.pdf

Welder, R. M. \& Champion, J. (2011). Toward an understanding of graduate preservice elementary teachers as adult learners of mathematics. Adults Learning Mathematics: An International Journal, 6(1), 20-40. Retrieve (Open Access) from: http://www.almonline.net/images/ALM/journals/almij-volume6_1_feb2011.pdf

Welder, R. M. \& Jong, C. (2012). Examining connections between mathematical knowledge for teaching and conceptions about mathematics teaching and learning. In L. R. Van Zoest, J.-J. Lo, \& J. L. Kratky (Eds.), Proceedings of the 34th Annual Conference of the North American Chapter of the International Group for the Psychology of Mathematics Education (pp. 773-776). Kalamazoo, MI: Western Michigan University. Retrieve (Open Access) from: http://www.pmena.org/pmenaproceedings/PMENA 342012 Proceedings.pdf

Welder, R. M. \& Simonsen, L. M. (2011). Elementary teachers' mathematical knowledge for teaching prerequisite algebra concepts. Issues in the Undergraduate Mathematics Preparation of School Teachers: The Journal, 1: Content Knowledge, 1-16. Retrieve (Open Access) from: http://www.k-12prep.math.ttu.edu/journal/1 .contentknowledge/welder01/article.pdf

Yow, J., Eli, J., Beisiegel, M., McCloskey, A., \& Welder, R. M. (2016). Challenging transitions and crossing borders: Preparing novice mathematics teacher educators to support novice K-12 mathematics teachers. Mathematics Teacher Education and Development, 18(1), 52-69 [last three authors listed alphabetically to indicate equal authorship]. Retrieve (Open Access) from: https://www.merga.net.au/ojs/index.php/mted/article/view/222 
Zaslavsky, O. (2007). Mathematics-related tasks, teacher education, and teacher educators. Journal of Mathematics Teacher Education, 10(4), 433-440.

Zazkis, R. \& Chernoff, E. J. (2008). What makes a counterexample exemplary? Educational Studies in Mathematics, 68(3), 195-208.

Zazkis, R., Liljedahl, P., \& Chernoff, E. J. (2008). The role of examples in forming and refuting generalizations. ZDM, 40(1), 131-141.

Zopf, D. (2010). Mathematical knowledge for teaching teachers: The mathematical work of and knowledge entailed by teacher education. (Unpublished doctoral dissertation). The University of Michigan, Ann Arbor, MI. Retrieved from http://deepblue.lib.umich.edu/bitstream/2027.42/77702/1/dzopf_1.pdf 


\section{Appendix A: Manuscript Review Rubric}

\section{Reviewer's Last Name:}

Manuscript Number:

Each section below contains bolded criteria to guide your review. For each section, check the box corresponding to the score you wish to assign and provide written feedback for authors and editors on the following page.

\begin{tabular}{|c|c|c|c|}
\hline $\begin{array}{l}\text { Most criteria (from score } \\
4 \text { ) are not met and/or } \\
\text { require major revisions }\end{array}$ & $\begin{array}{l}\text { Most criteria (from score } 4 \text { ) are } \\
\text { met with possibly one or more } \\
\text { criteria needing major revisions }\end{array}$ & $\begin{array}{l}\text { Most criteria (from score } 4 \text { ) are } \\
\text { met with possibly one or more } \\
\text { criteria needing minor revisions }\end{array}$ & $\begin{array}{l}\text { Introduction is clear, addresses } \\
\text { the importance of the work, is } \\
\text { grounded in the literature, and } \\
\text { provides clear guidance }\end{array}$ \\
\hline Score $=1$ & Score $=2$ & Score $=3$ & Score $=4$ \\
\hline
\end{tabular}

Audience: Manuscript is written for a wide variety of mathematics teacher educators (MTEs) who teach content to K-8 prospective teachers (PTs), including but not limited to mathematicians, adjunct faculty, graduate students, and former K-12 teachers. Manuscript sufficiently explains and limits the use of technical terminology, acronyms, and language with which some audiences may not be familiar.

\begin{tabular}{|c|c|c|c|}
\hline $\begin{array}{l}\text { Both criteria (from score } \\
\text { 4) are not met and/or } \\
\text { require major revisions }\end{array}$ & $\begin{array}{l}\text { Both criteria (from score } 4 \text { ) are } \\
\text { met with one criterion needing } \\
\text { major revisions }\end{array}$ & $\begin{array}{l}\text { Both criteria (from score } 4 \text { ) are } \\
\text { met with possibly one criterion } \\
\text { needing minor revisions }\end{array}$ & $\begin{array}{l}\text { Manuscript is written for a wide } \\
\text { variety of MTEs and sufficiently } \\
\text { explains the use of technical } \\
\text { terminology }\end{array}$ \\
\hline Score $=1$ & Score $=2$ & Score $=3$ & Score $=4$ \\
\hline
\end{tabular}

Connections to Theory: Manuscript makes substantial and meaningful connections to theory that appropriately and relevantly inform recommendations and/or suggestions for mathematics teacher educators (MTEs) who teach content to K-8 prospective teachers (PTs).

\begin{tabular}{l|l}
$\begin{array}{l}\text { Limited or no } \\
\text { connections to theory } \\
\text { have been made }\end{array}$ & $\begin{array}{l}\text { Some connections have been } \\
\text { made but additional } \\
\text { connections may be needed or } \\
\text { require major revisions }\end{array}$ \\
Score $=1$ & Score $=2$
\end{tabular}

\begin{tabular}{|l|l}
$\begin{array}{l}\text { Some connections have been } \\
\text { made, but additional connections } \\
\text { may be needed or require minor } \\
\text { revisions }\end{array}$ & $\begin{array}{l}\text { Sufficient, substantial, and clear } \\
\text { connections have been made }\end{array}$ \\
Score $=3$ & Score $=4$
\end{tabular}

Implications for Practice: Manuscript provides explicit, substantive, meaningful, and useful "practice-based" recommendations and/or suggestions for mathematics teacher educators (MTEs) who teach content to K-8 prospective teachers (PTs).

\begin{tabular}{|c|c|c|c|}
\hline $\begin{array}{l}\text { Limited or no } \\
\text { recommendations have } \\
\text { been made }\end{array}$ & $\begin{array}{l}\text { Some recommendations have } \\
\text { been made, but additional } \\
\text { connections may be needed or } \\
\text { require major revisions }\end{array}$ & $\begin{array}{l}\text { Some recommendations have } \\
\text { been made, but additional } \\
\text { recommendations may be } \\
\text { needed or require minor } \\
\text { revisions }\end{array}$ & $\begin{array}{l}\text { Sufficient, substantive, useful, } \\
\text { and clear recommendations have } \\
\text { been made }\end{array}$ \\
\hline Score $=1$ & Score $=2$ & Score $=3$ & Score $=4$ \\
\hline \multicolumn{4}{|c|}{$\begin{array}{l}\text { Writing Quality: Manuscript is well-written, easy to read and follow, organized in a logical manner, and of appropriate length } \\
\text { for the content. }\end{array}$} \\
\hline $\begin{array}{l}\text { Most criteria (from score } \\
\text { 4) are not met and/or } \\
\text { require major revisions }\end{array}$ & $\begin{array}{l}\text { Most criteria (from score } 4 \text { ) are } \\
\text { met with possibly one or more } \\
\text { criteria needing major revisions }\end{array}$ & $\begin{array}{l}\text { Most criteria (from score } 4 \text { ) are } \\
\text { met with possibly one or more } \\
\text { criteria needing minor revisions }\end{array}$ & $\begin{array}{l}\text { Well-written, easy to read and } \\
\text { follow, and logically organized }\end{array}$ \\
\hline Score $=1$ & Score $=2$ & Score $=3$ & Score $=4$ \\
\hline
\end{tabular}


Final Recommendation:

\begin{tabular}{|l|l|l|l|}
\hline Reject & Accept with major revisions & Accept with minor revisions & Accept \\
& & & \\
\hline
\end{tabular}

Feedback for Authors: Based on your evaluation, please provide specific, constructive suggestions to be shared with the Authors (please include page or line number):

Feedback for Editors: Please provide specific comments for the Editors that will not be shared with Authors (please include page or line number). 


\section{Appendix B: External Reviewers (listed in alphabetical order)}

Michael Battista, Ohio State University

Tim Boester, University of Maine

Mary Alice Carlson, Montana State University

Joe Champion, Boise State University

Noelle Conforti Preszler, Pacific Lutheran University

Molly Fisher, University of Kentucky

Ryan Fox, Belmont University

Frank Gardella, Hunter College, CUNY

Barbara Garii, The New School

Lynsey Gibbons, Boston University

Dianne Goldsby, Texas A\&M University

Lynn Hart, Georgia State University

Heather Howell, Educational Testing Service

Elham Kazemi, University of Washington

Marta Kobiela, McGill University

Torrey Kulow, Portland State University

Teruni Lamberg, University of Nevada, Reno

Douglas Lapp, Central Michigan University

Christine Latulippe, Norwich University

Yi-Jung Lee, University of Georgia

Wenjuan Li, New York University

Jane-Jane Lo, Western Michigan University

LouAnn Lovin, James Madison University

Kathleen Lynch-Davis, Coastal Carolina University

Joanna Masingila, Syracuse University

Betsy McNeal, The Ohio State University

Carl Olimb, Augustana University

Michelle Reed, Wright State University

Matt Roscoe, The University of Montana

Jacqueline Sack, University of Houston-Downtown

Alejandra Salinas, Boston University

Bart Snapp, The Ohio State University

Michael Steele, University of Wisconsin Milwaukee

David Tsay, University of Texas Rio Grande Valley

Andrew Tyminski, Clemson University

Eugenia Vomvoridi, University of South Florida

Hiroko Warshauer, Texas State University-San Marcos

Nina White, University of Michigan

Trena Wilkerson, Baylor University

Orit Zaslavsky, New York University 
Appova, Welder, \& Feldman, p. 366 